\title{
Canadian Somali Studies: Resilience and Resistance Conference Report
}

\author{
Nimo Bokore, MSW, PhD \\ School of Social Work, Carleton University \\ 618 Dunton Tower, Ottawa, K1S 5B6, Canada
}

Received: November 3, 2018 Accepted: December 3, 2018 Published: December 5, 2018

doi:10.5296/ijsw.v5i2.14001ＵRL: https://doi.org/10.5296/ijsw.v5i2.14001

\begin{abstract}
This first ever multidisciplinary, day-long colloquium highlighting the reflections on the resilience and the diversity in the experiences of the first and second-generation Somali-Canadians and beyond was organized in 2017 by Carleton University in Ottawa. This colloquium was designed to create a dialogue between Somali students, academics, and the community and was supported by community partners, the Migration and Diaspora Studies (MDS) Initiative, School of Social Work and School of Indigenous \& Canadian Studies at Carleton University. In this paper, I will be presenting notes from this day long colloquium covering topics such as mental health, education, the multiple identities of Somali Canadian youth and the relationship of Somali-Canadians to other communities such as Indigenous nations and other black diasporic communities.
\end{abstract}

\section{Welcome \& Opening Addresses}

The day began with an opening prayer by Barbara Dumont-Hill, an Algonquin elder from Kitigan Zibi Anishinabeg First Nation. This was followed by welcome addresses by Dr. André Plourde, Dean of Faculty of Public Affairs, Dr. Gerald deMontigny, Director of the School of Social Work, Dr. Peter Thompson, Director of the School of Indigenous/Canadian Studies, and I, Dr. Nimo Bokore, as the primary organizer of the colloquium. The morning and afternoon sessions ran consecutively and were organized around the main topics of the colloquium: mental health, the importance of higher education, the current high school dropout rates, dealing with the impact of historical trauma, belonging and identity, and current issues of carding and the death of multiple Somali-Canadian youth since 2008. Each session began with one of the featured presentations followed by other colloquium topics.

During lunch break participants enjoyed a hot Somali meal provided by the Migration and Diaspora Studies Initiative at Carleton and a visit to the art exhibit "Metropolitan Nomads: A Journey through Johannesburg's Little Mogadishu," a photographic exhibition organized by 
the Department of History. At the end of the afternoon sessions a roundtable discussion about the past, present, and future of Somali studies occurred before the colloquium closed at 4:30 pm.

\section{Morning Sessions}

\subsection{Mental Health and Somalis - Nimo Bokore, Carleton University}

I began the morning panels with one of the featured presentations using the findings from my study. In this presentation I addressed the vulnerability of some of the older generation of Somalis who harbour traumatic experiences of war and who are suffering from a variety of psychological disturbances such as: depression, anxiety, posttraumatic stress disorder (PTSD), and dissociation. Talking about the impact that this trauma now has on the younger generation I referenced the life story of Abdurrahman Abdi, who was killed in Ottawa in 2016 by the police, as a way to discuss the gaps in research, services, and the need for policy as well as changes in programming for resettled refugees.

Continuing with the mental health discussion, I spoke about the impacts of forced migration or escape from conflict zones, where there is the possibility of facing sexual violence and other human rights abuses on women and children. I used examples of wars in the Somali regions in the Horn of Africa, travelling through areas where the HIV/AIDs prevalence rate was adding to the risks of escape in hostile zones with a higher possibility of gender-based violence. I shared my own personal stories traveling through these zones and how the women I interviewed for my study felt about their journey to safety. I explained the difficulties these women and I faced not only from human aggressors, but also the possibility of death from exposure, starvation, or animal attack. They are unforgettable traumas which remain within our minds for some of us, creating the possibility of trauma transference to the second generation.

I also reminded the attendants about Somalis' resilience and inner strength that kept us alive through these recent ordeals of forced migration but also past colonial punishments including genocide, forced displacement and the divisions our parents faced. Throughout history Somalis as an ethnic group of survivors often show their ability in bouncing back with new skills that help them navigate the toughest situations, such as forced migration, facing xenophobia in refugee camps and racism/marginalization in resettlement, with incredible adaptations. Using as an example the booming businesses lead by mainly Somali-Canadian women I discussed their adaptation process in spite of being left with raising children alone and managing life in a country where they sometimes do not speak the language.

In my presentation, I also addressed acts of resistance taken by some community members against sources of trauma such as race, racialization and the Othering they face in their new country. For example, in Canada Somalis are categorised as Black, an identity that seems foreign to them as Somali identify themselves proudly with their tribal identities and their religion. Since they have their own internal tribal marginalization that was discussed in detail at the colloquium they understood what it means to be treated as the marginalized Madhibaan/Midgaan or Gaboye tribes. After their arrival they knew what being labelled Black means, which forces individuals into a category that is met with discrimination and inequality and they responded to it with resistance. They fought this socially constructed 
category of marginalization by maintaining their culture, religion and status quo. This resistance includes adherence to strict or extreme Islamic teachings including wearing certain clothing and behaviours. For those who followed this resistance it brought them further stress through isolation and lack of socioeconomic integration.

Therefore, the stressors of migration and past ordeals continue for some Somali-Canadians as trauma continues to be transposed from one generation to the next (Schwerdtfeger \& Goff, 2007; Robertson et al., 2006). In this presentation, I addressed how this phenomenon is currently manifested in behaviours and coping strategies of many Somali young men (Bhui et al., 2006; Bokore, $2009 \&$ 2018). An estimated 70\% of Canadian-Somali youth exhibit the effects of trauma, resulting in behavioural problems, addictions, gang membership, and even participation in extremist religious groups that build on youth vulnerability and impressionability as a recruitment strategy (Bokore, 2016, 2018, Jibril, 2011 and YCS, 1999). This youth related phenomenon was discussed throughout the presentations at this colloquium.

Lastly, I reiterated my reasons for holding this colloquium. As a Somali-Canadian, I have experienced the same barriers and hardships as countless other members of this community. Having dedicated my career to serving the Somali community through my work and research, this project is extremely close to my heart. Due to limited knowledge production in the Somali-Canadian community, I wanted to plan a conference that would give Somali scholars the opportunity to share their journeys through colonization, forced migration, and resettlement.

\subsection{Historical Overview: Omar Ugas, the Canadian Mental Health Association (CMHA), Ottawa}

Mr. Ugas gave a short overview of Somali history, using the work of other scholars to discuss resettlement experiences and mental health/health related challenges. Somalia was divided into regions in the 1884 African Partition (Cassanelli, 1982; Lewis, 1961 and Samatar, 1994). The regions that regained their independence in the 1960s created the Somali Republic, which disintegrated in 1991 with the fall of Mohamed Siyad Barre's government (Kagwanja, 2000; Kapteijns, 2008; Samatar, 1991). Somalis are one of the newest settler communities in Canada, having arrived in late 1990s and early 2000s as refugees and asylum seekers. Statistics Canada estimated the Canadian population of Somalis in 2006 to be 37,785. However, the 2011 Statistics Canada report shows a decline in population, with an estimated population of 31,380 (Statistics Canada, 2006, 2011).

In 2006, the population of Ottawa, where this colloquium was held, included 8,000 self-identified ethnic Somalis (Orenstein, 2006), while in 2011 that number had declined to 6,135 . Undocumented community reports suggest that this population decrease was caused by the lack of economic/social integration of Somali youth. The younger generation of Somalis faces multiple barriers in the education system and the labour market, which has resulted in an identity crisis (Abdi, 2012; Bokore, 2016, 2018 and Jibril, 2011).

\subsection{Somali Stories as a Site of Knowledge (Re/De) Construction - Hawa Mire, Carleton University}

Mire, a PhD student at Carleton University, described how the power of the diaspora lies in 
its ability to allow multiple truths to emerge, and theorized Somalis' understanding of migration. Mire examined methodologically Somali origins and myths as a site of contention and as social construction of identity and power. She incorporated colonial anthropological texts and Somali oral stories to examine the contemporary Somali-Canadian diaspora's response to the identity of the Madhibaan, a marginalized Somali group found throughout the Somali territories. This was an enlightening conversation, especially considering that Somalis are now finding themselves being categorized as Black, an identity that is foreign to them and carries additional marginalization implications such as barriers to higher education (Dei et al., 1997; Dei \& Cassliste, 2000).

\subsection{The Power of Sharing Personal Stories - Khalid Egeh, a Public Speaker from the Ottawa Area}

Egeh, a young Somali man, shared his personal experience of systemic marginalization as a Black youth in Canada while also battling severe health issues. He detailed his journey as a young boy who was told that he would not be able to walk, but how he graduated in a timely fashion, meeting these challenges with perseverance, resilience, and resistance. He described himself as humble, faithful, and patient. With tears in his eyes, he described his own marginalization as a black, Muslim youth. He also spoke about his refusal to accept the stereotypes place on him and Somalis. He concluded his presentation with a moving commitment to an example of hope for other Somali youth, but also "for people from coast to coast, [all] ages and genders, embodying endurance, perseverance, and success."

\subsection{The Impact of Carding on the Somali Diaspora in Ontario - Younis Mohammed, Toronto.}

Younis spoke about carding, policing, and surveillance, particularly as it pertains to Toronto. Younis discussed the role of racism in carding, particularly in relation to the checks and balances (e.g., Ontario Regulation 58/16 that obligates police officers who voluntarily stop individuals on the street to inform them first that they have the right not to give any identifying information) that are often ignored.

Younis asserted that carding disproportionately affects those from marginalized communities. For example, in 2015, the Ottawa Police Service accumulated statistics from 2011-2014 showing that $20 \%$ of people they had street checked were Black. However, according to the National Household Survey, in 2011 Black people accounted for only 5.7\% of Ottawa's population. As evidenced in the Toronto Star's analysis of 1.7 million contact cards filled out by Toronto police officers between 2003 and 2008, Black people across Toronto were three times more likely to be stopped and documented by police than white people.

\subsection{The Commonalities and Differences in the Experiences of Somalis and Indigenous People - William Felepchuk, Carleton University}

Felepchuk, a PhD Candidate at Carleton University, discussed how white settlers in Canada positioned themselves as the dominant subjects of the nation and knowledge by the telling of demeaning stories about Indigenous communities and later about Somali/Black communities. He noted the importance of underscoring that neither Indigenous nor Somali communities fit these descriptions of white settlers. Felepchuk was one of several presenters who drew parallels between the Indigenous and Somali communities' experiences including cumulative, intergenerational, emotional and psychological wounds. 
2.7 Identity, Belonging, and Resistance among Dutch-Somali Youth - Valerie Stam, Carleton University

Stam, a $\mathrm{PhD}$ Candidate at Carleton University, instigated a discussion on identity and belonging for immigrant youth in the Netherlands, highlighting how children of immigrants often manage complex identities, with one foot in their home culture and one foot in their host culture. Stam described how the multiple intersecting identities of first- and second-generation immigrant youth play out in the wider context of contested citizenship in this European nation. While the youth hold de facto legal citizenship (formal membership), their de jure citizenship (social membership) is often questioned (Arendt, 1951 and Somers, 2008).

Stam discussed how being black or Muslim makes youth vulnerable to frequent discrimination in their host societies. She spoke about the daily micro-aggressions, the archetype of the good, or ideal, citizen, and discourses of tolerance of certain bodies (Brown, 2008; Essed, 1991; Thobani, 2007 and Yuval-Davis, 2011). Based on interviews and a participatory theatre project with second-generation youth from a variety of backgrounds in the Netherlands, her presentation described the ways in which Dutch-Somali youth are claiming and exploring their identity as black, Somali, Muslim, and Dutch.

\section{8 (Re) Constructing Identities: Somali Womanhood in Canada-Muna Ali, York University,}

\section{Ontario}

Muna Ali discussed the ways in which Somali women in Canada re-imagine what it means to be Somali, Muslim, black, feminist, and woman, and how these identities play out in terms of work, education, relationships, power, and social advancement. She emphasized how the use of a conceptual framework of intersectionality allows new immigrant and youth voices to interrogate identity as a social construction, theorize about race, explore the social construction of gender according to normative and racialized assumptions, and examine the construction of alternative religious and cultural identities as they relate to the gendered "othered." In her presentation, she included details of the social construction of Somali womanhood in Canada and its role in defining the occurrence of "resistance and resilience" through the intersecting lenses of gender, race, class, ethnicity, and religion.

\section{Afternoon Sessions}

3.1 Reflections on the Limits of School Suspension Data: The Case of Somali Boys in Toronto - Mohamed Duale, York University, Ontario

The afternoon session began with another featured presentation by Mohamed Duale, a PhD student in the Faculty of Education at York University, presenting his research on the limits of school suspension data on black students using male Somali studies in Toronto as a case study. He discussed how in recent years, there has been a call for public institutions such as school boards to collect and publish disaggregated data on student achievement. He explained that although disaggregated data can play an important role in improving transparency, it has its limits on school suspension data in accounting for the schooling experiences of racialized youth in general, and Somali students in particular.

The Toronto District School Board's (TDSB) published disaggregated data shows that Somali students have the highest suspension rate $(7.4 \%)$ of any linguistic group in the Board. Despite 
its usefulness in exposing glaring differences in outcomes, the Board's disaggregated data does not say much about why Somali students are disproportionately suspended. Additionally, much of the data on Somali students is not disaggregated by gender or income, leaving us with an incomplete picture. His informative presentation used critical race and post-structuralist theories to argue for the need to supplement disaggregated data with the voices of the affected students to reveal how profiling and surveillance in everyday and undocumented ways informs how Somali students come to experience schooling in the Toronto District School Board.

Mohamed drew from Abdi's (2012) work and the accounts of three boys work whose stories shed new light on Somali students' encounters with school authority figures.

The first example was Abdul (synonym name):

The principal was always trying to find a reason to get rid of me, right? So one day he found "a reason" and he was trying to suspend me but then I came here [the private school where the focus group discussion took place]. I basically beat him to it. (Abdi, 2012, p. 88)

In addition to being under constant surveillance, Abdul described his negative interactions with other auxiliary staff, including a police officer at school who stereotyped Somali students as troublesome and underachieving.

The police officer at my school started chatting with me one day and said to me something like, "Somalis have the lowest marks in all of TDSB and they are the highest to go to jail in Toronto." He said to me, "The Somalians have the highest failure rate in Math and English in the whole TDSB." So I did not believe him, right? So I said to him what does that have to do with me, right? So he says to me: "You tell me."

The second example detailed Awale's (synonym name) experiences:

I was kicked out of school X in Grade 9. My friends and I were walking to our classes right after the bell rang, the principal chased us like we were criminals or something, took us to the office and said, "aren't you supposed to be in class?" We were already headed there but we were kicked out together just because we were a minute behind. In Grade 10 we [his family] moved to Dubai. I lived in Dubai for one year but I did not go to school there. Me, my brothers and sisters were learning Qur'an at home. When I came back, I went back to school X but they gave me a hard time. Suspending me and what-not. So, I transferred to school Y.

Third and final example he used was Sharmarke's story (synonym name):

Basically, I was in a drama club and it was during the time of Halloween, so our class was decorating to make the room look like a haunted house; so then we decorated everything - we put up those balloons, all of these decorations. And during the lunch hour we charged people a dollar to come in and enjoy the haunted house. We were basically fundraising for our class so that we could go on a trip. I was one of the students who was there, and I accidently popped a balloon which caused a disturbance in the room. So now I am in 
trouble because I was the one who stepped on the balloon and popped it. It was all fun and games, but I got suspended for popping a balloon in class. Somebody else might look at it like, "that is ridiculous how can you get kicked out for popping a balloon?" But that just shows you that the principals are not fair to some students (Abdi, 2012, p. 92).

Mohamed, drawing on Farhia Abdi's (2012) study, also offered many other stories of young men and women who, because of excessive scrutiny and undeserved punishment, found themselves excluded from the benefits of a public education. Being regularly profiled and suspended deleteriously impacts the education of affected students largely because of reduced instructional time and the discouragement that is often the result of suspension and the challenge of making up for missed school work. The boys' accounts reveal a Somali student population that is subjected to unusual levels of discipline and punishment. Yet much of the TDSB's published literature does not include the perspectives of suspended students to the detriment of well-intentioned equity initiatives seeking to address the disparities being faced by minoritized demographics. Mohamed concluded his presentation by discussing democratic and inclusive ways to address these disproportionate outcomes when it comes to accessing higher education by Somalis and other black students in Canada.

3.2 Somalis on Campus: Black Muslim Identities Existing in the Academy - Muna Udbi, Huda Hassan, Jama Haji Yusuf, Osman Kahiye, and Ahmed Elmi

A panel of $\mathrm{PhD}$ and master's students from OISE/University of Toronto and Concordia University presented on black and Muslim identities in Canada. They began their discussion with the 2015 \#BlackOnCampus movement that became a viral social media discussion after anti-black racism was identified at the University of Missouri. They talked about what happened in Canada after that movement and how students are using \#BlackOnCampus as a protest model. They discussed student activities across campuses working to support international Black movements to resist anti-black racism and dubious hiring practices that still see Black faculty as severely underrepresented in Canada.

According to Statistics of Canada (2006), Somalis are the largest African diaspora in Canada and the most visible black Muslim demographic in the country. The panel addressed how carrying the Black Muslim label had an impact on accessing education, and the members spoke of how they navigated within the Canadian academic structure. In an interesting and insightful conversation, they connected their experiences with the larger issues of inequity in the academic structures and Canada as a whole.

\section{Afternoon Roundtable Discussions: Mapping Somali Studies in Canada}

The day-long colloquium concluded with roundtable discussions based on specific questions addressing the future of Somali studies in Canada. The questions where designed to stimulate conversation on Somalis' past, present, and future studies (refer to appendix 1 for details).

\subsection{The Past}

The group discussing the past focused on understanding Somali history, including turning points in the country's politics and culture. Participants in this roundtable identified how important it is to talk about Somalia's colonial past, emphasizing the impact of the 1884 African Partition at the Berlin Conference. It was agreed that Somalia's colonial history is 
remembered mainly by the older generation and those who are studying historical events in Africa.

The group also noted how knowledge about the pre-Islamic and pre-war socialist era is important to future Somali studies as a knowledge transfer. Some round table members mentioned the need to focus on identifying Somali historical moments that heighten the pride, strength, and resilience of Somalis. Using examples of how Somalis built cities that were the center of civilization in east Africa such as Zeila, Harar, Barbara and Mogadishu, the roundtable participants emphasized the need for positive stories rather than negative ones. Past stories are filled with western perceptions and bias by white and male knowledge holders, communicating in their writing the things that are wrong in our culture and way of life. They used examples of how the negative representations of Somalis of Burton (1856) and James (1888) initiated the use of racialized and oppressive language to label and perpetuate the marginality of Somalis. The group at this table said knowing this past reminds us not to forget a part of our history that was traumatizing, and that labeled Somalis for the purpose of marginalization and dislocation of a people from their lands, history, politics, and economy. This group also talked about the positive gendered history that occurred during the pre-war socialist era (1969-1991) and delved into a discussion of gender equality. Some of the participants reminded the group that this period in Somali history needs to be noted as an era where issues of gender equality were introduced and where the elimination of tribal divisions and restoration of ethnic identity was promoted.

\subsection{The Present}

Participants of this round table discussed the state of current Somali studies. They also pointed out the lack of studies on the accumulated trauma starting from the colonial partition that divided not only the land, but also the people and Somali politics. They argued that this social and political divide now extends to the diaspora, creating additional stressors and a barrier to building social support systems. The discussion also included the impact of post-war Islamic politics, postcolonial historical trauma, and trauma transference in relation to the identity crisis of Somali youth. Panelists described the confusion surrounding religious practices and a measure of religiosity, which is contested based on individuals families' religious practices. This was an in-depth conversation that brought in youth voices who spoke about the stressful conversations they have with their parents and community members that are impacting their wellbeing and particularly, the traumatic stories that are shared by some families.

Post-war Islamic politics created unclear social norms that led to religious and cultural stress. For the diaspora youth in particular, the strict social norms often enforced by interest groups and those who embraced this new social norm enforced on them because of their ignorance of accurate religious teachings result in isolation and low self-esteem. One of the examples mentioned in this discussion was the disapproval of some community members of cultural songs and visiting the burial places of historical or religious figures. For youth who already feel isolated from mainstream Canadian society, facing the challenge of not belonging to their own community is extremely harmful. Currently in the Somali community, it is common to be judged for not attending a certain mosque or not adhering to certain religious beliefs, which is very stressful especially for vulnerable youth. 
Looking back at the history of Islam and the Somali regions, participants at this table discussed how Islam was introduced to Somalis centuries ago and how throughout history, religious practices have been contested based on the leader at the time who would often promote gendered religious and oppressive ideological teachings. Some of those leaders used these restrictive interpretations of Islamic teachings to maintain power. Participants at this table, mainly women, also discussed the silencing of women who, looking back, shared the teachings by Sufism, Sunnism, and Ahmadiya even before the arrival of the current Wahhabism in the late 1970s. The discussion also touched on the impact of the changing nature of religious teachings and leaders had on women before or after Siyad Barre's regime and his scientific socialism, an ideology that was based on a version of socialism that is compatible with Qur'anic principles. Participants at this round table concluded how important it is to critically analyze current Somali studies that carry labels taken up by early Somali studies which are damaging at times and acknowledging them as "Cadaan Studies," or studies done by non-Somali historians, and how creating our own knowledge is important for future Somali studies.

\subsection{The Future}

The group at this table addressed what they called the impact of media representation of Somali youth. They discussed the importance of moving the story beyond humanitarian intervention that is often based on assumptions and mislabeled community image. They talked about how the media in early 1990s Canada presented the news of the death of a young Somali youth who was killed by Canadian soldiers. While the media depicted this death as caused by rogue soldiers, researchers like Razack (2004, p. 4) pointed out this story is based on a discourse of the civilized West (us) and the backward Africans (them) that was clearly present in the coverage. The discussion at this table continued on the topic of the exclusionist media sources that often fed the public a post-9/11 hysteria and public fear of Muslims. Furthermore, when stories of Somali youth appear in Canadian news media and internet postings, the focus is usually on the Somali youth's involvement with violence. They focus on drugs and the few involved in the drug trade and blame parents for sending their children to fight overseas for Islamic causes, including Al-Shabaab and ISIL (Aulakh, 2010; Brown, 2006, 2014; The Canadian Press, 2010; Said, 1979).

The roundtable group also discussed the international media representations of Somalis that focus on fractured governments, pirates, famine, and its relation to population displacement. This characterizes Somalis as backward people/savages, recipients of humanitarian aid, and victims of internal wars and urban drug warfare here in Canada. Reports on international terrorism after 9/11 often connect Al-Shabaab with Al-Qaeda, which evokes fear and mistrust of Somalis. To overcome negative media portrayal, the group suggested creating counter social media reports or contributing a positive news story of the many Somali-Canadians who are doing well.

The role of academia and the lack of funding for research that would benefit the community including mental health, health, education, and careers was discussed. Crowd sourcing is one avenue of self-funding for future beneficial research projects.

Historicizing Somali-Canadian history by learning about our roots and culture, including information sharing through poetry was also discussed as an important part of Canadian 
Somali studies. They said this would increase youth engagement and establish trust when the youth get the chance to learn about their history and cultural communication methods. The teaching of the culture or Dhaqan in Somali for Somali children was also empathized as a meaningful education that builds children's self-esteem at a young age. Others mentioned creating resources for alternative education that celebrates Somali and Black history, including program development. Some mentioned seeking support from other Black Canadians who have experienced oppressive systems for centuries. This group concluded their discussion with the need to develop an honest conversation that is based on bi-culturalism that covers gender identity, bi-cultural expressions, and sexuality.

\section{Discussion: Canadian Somali Studies}

Canadian-Somali studies must begin with an exploration of the history of the diaspora. The written historical facts about the Somali community whether accurately recorded or not, play a major role in our interpretation of the contemporary social world we live in. Canada received about 38,000 Somalis in the late 1990s and early 2000s following the collapse of the Somali government. Colonial history informs us that the process of identity and belonging began with the first colonial settlers/Europeans and the displacement of Indigenous groups, including Somalis. Upon arrival to Canada, Western Europeans who dominated the early history of Canadian immigration soon positioned the Indigenous population and others as subordinates. Where do Somalis fit into this history? Somali studies require historical reminders on community issues including the current economical inclusion and belonging. It requires a critical engagement with historical marginalization based on race and most recently, geopolitical location.

Future Canadian Somali studies need to empathize community resilience, resistance and survival ability. One unforgettable point in Somali studies should be remembering that for Somali ethnic groups, community and belonging are the roots of their social structure/culture. The word, "Somali" means, "go milk an animal for yourself." A word that explains Somali pastoralist hospitality of community, strong tribal connections, and healing through Islamic teachings. Even though Somalis are an ethnic group comprised of separate tribal identities, this close connection is ruled by what is known as "heer", which translates as "customary law" and is the main source of communication, healing, and community development. All three roundtable discussions concluded by reminding the organizers that future Somalis studies need to include these basic aspects of Somali identity, culture, pride, and community.

\section{References}

Abdi, F. (2012). Kicked out of school: The perspectives of Somali students on why they have not completed high school (Order No. MR90060). Available from Dissertations \& Theses @ York University; ProQuest Dissertations \& Theses Global. (1221266628). Retrieved from http://ezproxy.library.yorku.ca/login?url=http://search.proquest.com/docview/1221266628?ac countid $=15182$

Arendt, H. (1951). The Origins of Totalitarianism. New York: Harcourt, Brace and Jovanovich.

Bokore, N. (2009). Female survivors of African wars dealing with the past and present. Journal of Sociological Research, 1(1), E5. https://doi.org/10.5296/jsr.v1i1.189 
Bokore, N. (2012). Suffering in silence: A Canadian-Somali case study. Journal of Social Work Practice: Psychotherapeutic Approaches in Health, Welfare and the Community.

Bokore, N. (2016). "Somali-Canadian Women: Historical Past of Survival and Facing Everyday Challenges of Resettlement". A Dissertation Submitted to The Faculty of Graduate Studies In Partial Fulfillment Of The Requirement For The Degree of Doctor Of Philosophy. Graduate Program in Social Work, York University, Toronto, Ontario. Retrieved from http://yorkspace.library.yorku.ca/xmlui/bitstream/handle/10315/32653/Bokore_Nimo_2016_ Phd.pdf? sequence $=2 \&$ isAllowed $=\mathrm{y}$

Bokore, N. (2018). Historical Trauma, Resettlement, and Intervention Strategies: An Analysis of Somali-Canadian's Experiences. Journal of International Migration. https://doi.org/10.111 1/imig. 12418

Bhui, K., Craig, T., Mohamud, S., Warfa, N., Stansfeld, S.A., Thornicroft, G, ... McCrone, P. (2006). Mental Disorders among Somali refugees: Developing culturally appropriate measures and assessing socio-cultural risk factors. Social Psychiatry and Psychiatric Epidemiology, 41, 400-408. https://doi.org/10.1007/s00127-006-0043-5

Brown, W. (2008). Regulating Aversion: Tolerance in the Age of Identity and Empire. Princeton, N.J.: Princeton University Press.

Cassanelli, L. (1982). The Shaping of Somali Society: Reconstructing the history of a pastoral people, 1600-1900. Philadelphia, PA: University of Pennsylvania Press. https://doi.org/10.978 3/9781512806663

Jibril, S. (2011). Cashberta: Migration experiences of Somali-Canadian second generation youth in Canada. Master of Environmental Studies (MES) Major Paper, 17(1).

Kapteijns, L. (1994). Women and the crisis of communal identity: The cultural construction of gender in Somali history. In A. I. Samatar (Ed.), The Somali Challenge: From catastrophe to renewal (pp. 221-32). London, UK: Lynne Riennner Publishers Boulder.

Kapteijns, L. (1999). Women's voices in a man's world: Women and the pastoral tradition in Northern Somali Orature, 1899-1980. Studies in African Literature. Portsmouth, NH: Heinemann Publishing.

Kapteijns, L. (2008).The Disintegration of Somalia: A Historiographic Essay. Bildhaan Vol. 1 .

Lewis, I. M. (1961). A pastoral democracy: A study of pastoralism and politics among the Northern Somali of the Horn of Africa. London, UK: Oxford University Press.

Ornstein, M. (2006). Ethno-Racial groups in Toronto, 1971-2001: A demographic and Socio-Economic Profile. Toronto, ON: Institute for Social Research, York University.

Robertson, C. L., Halcon, L., Savik, K., Johnson, D., Spring, M., Butcher, J., \& Jaranson, J. (2006). Somali and Oromo refugee women: Trauma and associated factors. Journal of Advanced Nursing, 56(6), 577-587. https://doi.org/10.1111/j.1365-2648.2006.04057.x

Statistics Canada. (2006). Population projection of visible minority groups, Canada provinces and regions, 2001-2017, Catalogue no. 91-541-XIE. Retrieved from http://publications.gc.ca/collections/Collection/Statcan/91-541-X/91-541-XIE2005001.pdf 


\section{Macrothink}

International Journal of Social Work

ISSN 2332-7278

2018, Vol. 5, No. 2

Statistics Canada. (2011). Detailed mother tongue: Total population excluding institutional residents.

Samatar, A.I. (Ed). (1994). The Somali Challenge: From catastrophe to renewal. London, UK: Lynne Riennner Publishers Boulder.

Schwerdtfeger, K. L., \& Goff, B. S. (2007). Intergenerational transmission of trauma: Exploring mother-infant prenatal attachment. Journal of Traumatic Stress, 20(1), 39-51. https://doi.org/10.1002/jts.20179

Somers, M. R. (2008). Genealogies of Citizenship: Markets, Statelessness, and the Right to Have Rights. Cambridge: Cambridge University Press.

Thobani, S. (2007). Exalted Subjects: Studies in the Making of Race and Nation in Canada. Toronto: University of Toronto Press.

York Community Services. (1999). A study on the mental health needs of the Somali community in Toronto. Prepared by Abdullahi S. Elmi. Retrieved from http://ceris.metropolis.net/Virtual\%20Library/health/elmi1.pdf

Yuval-Davis, N. (2011). The Politics of Belonging. London, Thousand Oaks CA, and New Delhi: Sage Publications.

\section{Appendix}

Appendix 1. Mapping Somali Studies

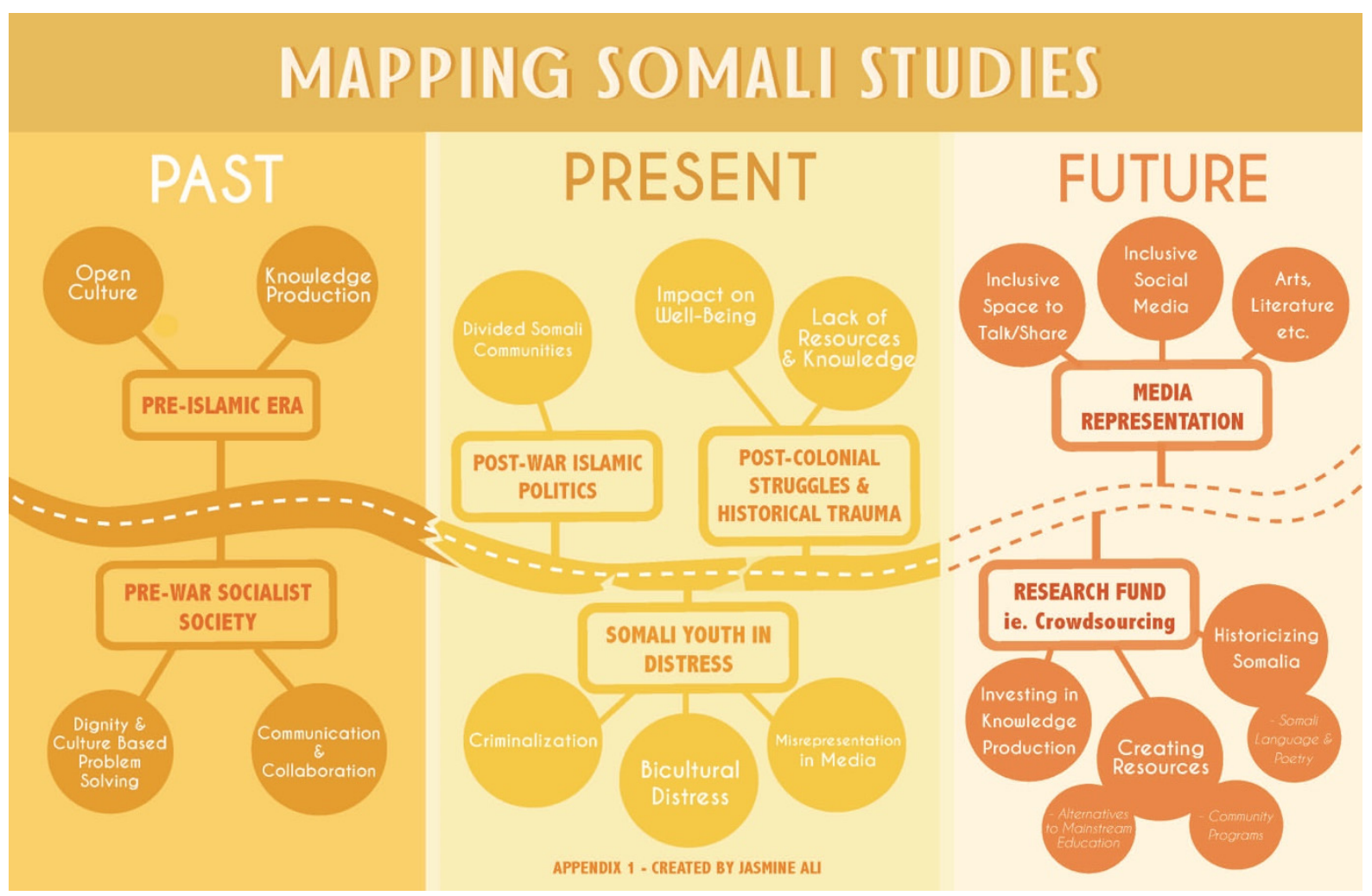




\section{Copyright Disclaimer}

Copyright reserved by the author(s).

This article is an open-access article distributed under the terms and conditions of the Creative Commons Attribution license (http://creativecommons.org/licenses/by/3.0/). 